\title{
Exhaled breath analysis: a review of 'breath-taking' methods for off-line analysis
}

\author{
Oluwasola Lawal $^{1,2,3}$ - Waqar M. Ahmed ${ }^{1,2,3}$ - Tamara M. E. Nijsen ${ }^{2}$. \\ Royston Goodacre $^{3} \cdot$ Stephen J. Fowler ${ }^{1,4}$
}

Received: 1 April 2017 / Accepted: 24 July 2017 / Published online: 19 August 2017

(c) The Author(s) 2017. This article is an open access publication

\begin{abstract}
Background The potential of exhaled breath sampling and analysis has long attracted interest in the areas of medical diagnosis and disease monitoring. This interest is attributed to its non-invasive nature, access to an unlimited sample supply (i.e., breath), and the potential to facilitate a rapid at patient diagnosis. However, progress from laboratory setting to routine clinical practice has been slow. Different methodologies of breath sampling, and the consequent difficulty in comparing and combining data, are considered to be a major contributor to this. To fulfil the potential of breath analysis within clinical and pre-clinical medicine, standardisation of some approaches to breath sampling and analysis will be beneficial.

Objectives The aim of this review is to investigate the heterogeneity of breath sampling methods by performing an in depth bibliometric search to identify the current state of art
\end{abstract}

Electronic supplementary material The online version of this article (doi:10.1007/s11306-017-1241-8) contains supplementary material, which is available to authorized users.

Stephen J. Fowler

stephen.fowler@manchester.ac.uk

1 Division of Infection, Immunity and Respiratory Medicine, School of Biological Sciences, Faculty of Biology, Medicine and Health, The University of Manchester, Manchester, UK

2 Philips Research, Royal Philips B.V., Eindhoven, The Netherlands

3 School of Chemistry, Manchester Institute of Biotechnology, The University of Manchester, Manchester, UK

4 Manchester Academic Health Science Centre, The University of Manchester and University Hospital of South Manchester NHS Foundation Trust, Manchester, UK in the area. In addition, the review will discuss and critique various breath sampling methods for off-line breath analysis. Methods Literature search was carried out in databases MEDLINE, BIOSIS, EMBASE, INSPEC, COMPENDEX, PQSCITECH, and SCISEARCH using the STN platform which delivers peer-reviewed articles. Keywords searched for include breath, sampling, collection, pre-concentration, volatile. Forward and reverse search was then performed on initially included articles. The breath collection methodologies of all included articles was subsequently reviewed.

Results Sampling methods differs between research groups, for example regarding the portion of breath being targeted. Definition of late expiratory breath varies between studies.

Conclusions Breath analysis is an interdisciplinary field of study using clinical, analytical chemistry, data processing, and metabolomics expertise. A move towards standardisation in breath sampling is currently being promoted within the breath research community with a view to harmonising analysis and thereby increasing robustness and inter-laboratory comparisons.

Keywords Breath sampling - Breath phases - Breath collection $\cdot$ Breath pre-concentration
Abbreviations
BCA Breath collection apparatus
CAR Carboxen
CW Carbowax
DVB Divinylbenzene
DMS Differential mobility spectrometry
ECD Electron capture detector
FID Flame ionisation detector
GC-MS Gas chromatography-mass spectrometry
MW Molecular weight 


$\begin{array}{ll}\text { NTDs } & \text { Needle trap devices } \\ \text { PA } & \text { Polyacrylate } \\ \text { PDMS } & \text { Polydimethylsiloxane } \\ \text { ppmv } & \text { Parts per million volume } \\ \text { ppbv } & \text { Parts per billion volume } \\ \text { SPME } & \text { Solid phase microextraction } \\ \text { TD } & \text { Thermal desorption } \\ \text { Tof } & \text { Time of flight } \\ \text { VOCs } & \text { Volatile organic compounds }\end{array}$

\section{Introduction}

Breath odours were used for disease recognition long before present-day diagnostics; a sweet smell was associated with diabetes mellitus, fish-like smell with liver disease, and urine-like smell with kidney disease (Phillips 1992). Exhaled breath is predominantly composed of nitrogen, oxygen, carbon dioxide, argon as well as water vapour, whereas the volatile organic compounds (VOCs) which may be diagnostically useful are only found in trace concentrations (Lourenco and Turner 2014). Identification of VOCs patterns via human olfaction for disease diagnosis is of course subjective, and modern analytical instruments have sought to make this more reliable and robust. This has led to a sustained interest in breath diagnosis due to its non-invasive nature, with the ability to take repeat measurements with little stress or discomfort to the individual under investigation.

The concept behind breath metabolomics (also known as breathomics) is that the VOC profile in breath will be altered when a switch from a healthy to a pathological state occurs and this can be detected and potentially utilised for diagnosis and monitoring (Beale et al. 2016). The origin of breath VOCs include the environment (termed exogenous), the host (endogenous), and also the microbiome (the microorganisms that inhabit the mouth, lung and gut) (Boots et al. 2015; Bos et al. 2013; Schulz and Dickschat 2007). Most of the identified VOCs in exhaled breath originate exogenously (Costello et al. 2014), but endogenous and microbial VOCs are of more interest clinically. Endogenous VOCs have the potential to provide a snapshot of the physiological state of an individual whilst microbial VOCs could aid in pathogen identification, and the interaction of the host and commensal microorganisms contributes significant complexity to the metabolome of this complex "superorganism" (Goodacre 2007). Breath VOCs are found at trace levels [typically parts per million volume (ppmv) and lower] and their reliable detection poses a challenge, hence the typical use of sample preconcentration coupled with a highly sensitive analytical instrument. Several methods are utilised for pre-concentration using thermal desorption chemistries such as solid phase microextraction (SPME) and needle trap devices (NTDs).

The off-line breathomics pipeline can be broadly broken down into breath sample collection, sample analysis, and data analysis (Rattray et al. 2014). There are several ways of achieving the desired goal in each section. For example, for breath sample collection, factors such as type of breath to be collected (i.e., mixed expiratory or end-tidal), single or multiple exhalation, and choice of breath capture technology are just some of the options to be considered (Fig. 1).

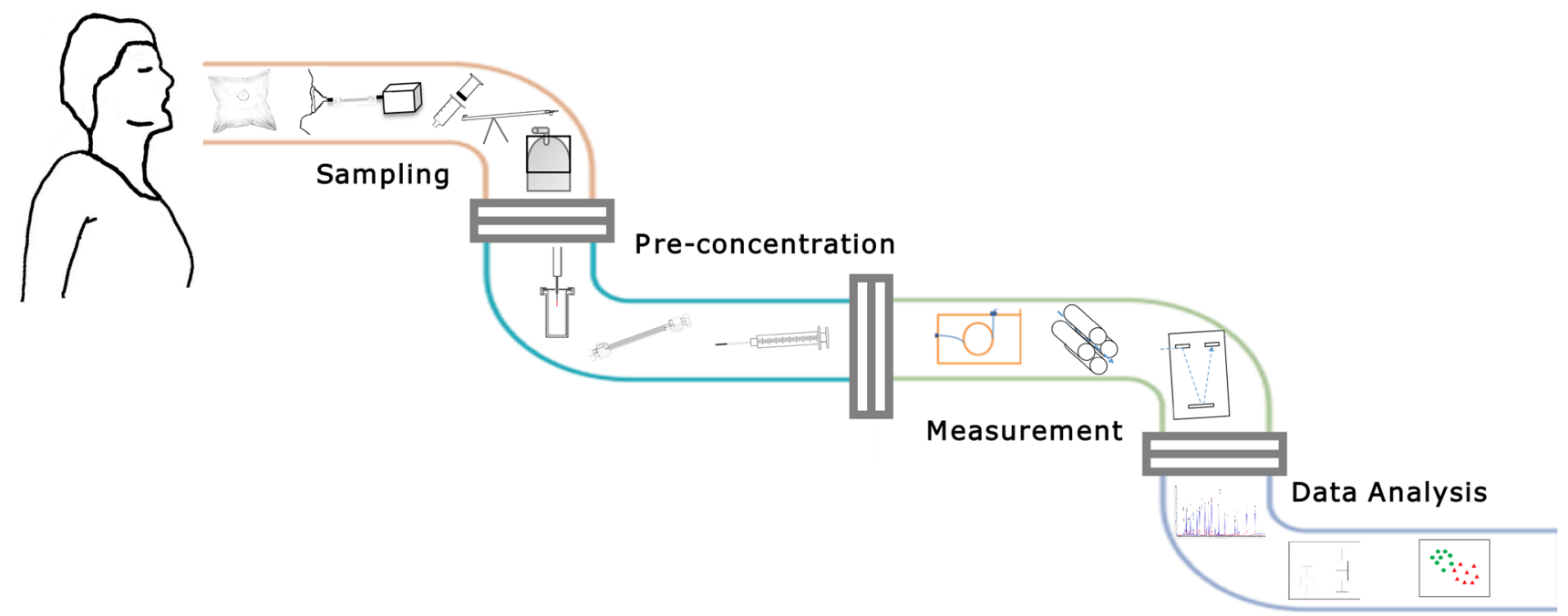

Fig. 1 A diagram illustrating the off-line breath sampling pipeline. First section shows breath sampling containers [From L to R gas sampling bag, face-mask, Bio-VOC ${ }^{\mathrm{TM}}$ Sampler, breath collection apparatus (BCA), canister], second section indicates pre-concentration methods [From L to R solid phase microextraction (SPME), Thermal desorption (TD) tube, needle trap devices (NTDs)]. Gas chromatograph (GC) and mass analysers [quadrupole, time-of-flight (Tof)] are in the third section and the fourth section depicts targeted and untargeted data pre-treatment, processing and analysis 
In this article, a summary of methods utilised in the offline breathomics pipeline across studies is shown, whilst evaluating heterogeneity between methods and suggesting where standardisation may be beneficial.

\section{Breathomics bibliography search criteria}

The search was conducted to include articles until the 24th of October 2016 and the overall process used is schematically shown in the supplementary material (Figure S1). To ensure quality, the STN platform (https://www.stn.org/stn/) was utilised which delivers peer reviewed articles only. Databases searched include MEDLINE, BIOSIS, EMBASE, INSPEC, COMPENDEX, PQSCITECH, and SCISEARCH. The search strategy included looking for (breath?) in article titles and ((sampl? OR collect? OR pre(W)concentrat? OR preconcentrat?) AND volatile) in the title and abstracts of articles. "?" and "W" denotes any number of characters to the right of the term and one character between two words (e.g. space or hyphen) respectively. In total, 395 manuscripts were obtained after automatic filtration. These articles were subsequently manually filtered to exclude review articles, breath condensate articles, articles with only real time analytical platforms, and also non-human studies. In the scenario where the same breath sampling methodology is used by the same first author in multiple articles, only one of the articles was included. To prevent bias, articles with the same breath sampling methodology and same last author (or thought to originate from the same laboratory) were classified together as one for descriptive statistics purposes. Additional articles were included following forward and reverse searching resulting in the final inclusion of 110 papers. From the final 110 articles the following parameters were assessed:

- Exhaled breath portion targeted

- Breath collection container

- Pre-concentration methods

A schematic representation of exhaled breath phases is depicted in Fig. 2 and thus the breath type categories were sub-categorised into: late expiratory breath (Table 1), sampling from the end-tidal or 'alveolar' breath (Table 2), and mixed expiratory breath (Table 3 ). Other breath types can be found in the supplementary information (Table S1).These tables include a brief description of how the breath type was obtained, and further categorisation was performed according to the type of breath collection container, as well as the pre-concentration method employed in the study.

\section{Sampling exhaled breath}

During breath sampling, there is a choice made as to the portion of the breath that can be collected, and this can be broadly divided into late expiratory, end-tidal, and mixed expiratory. Mixed expiratory breath sampling encompasses the total exhaled breath which includes 'dead space air' (air not involved in gaseous exchange including mouth and potentially nose air) while the other breath types aim to minimise contamination from this dead space. Each of the three main types of sampling will be discussed further.
Fig. 2 Schematic visual representation depicting a single exhaled breath phases by capnography. Late expiratory breath is undefined as there is no standard practice for collecting this breath type and definitions vary. Phase I dead space, Phase II transition, Phase III alveolar. Adapted from (Miekisch et al. 2008)

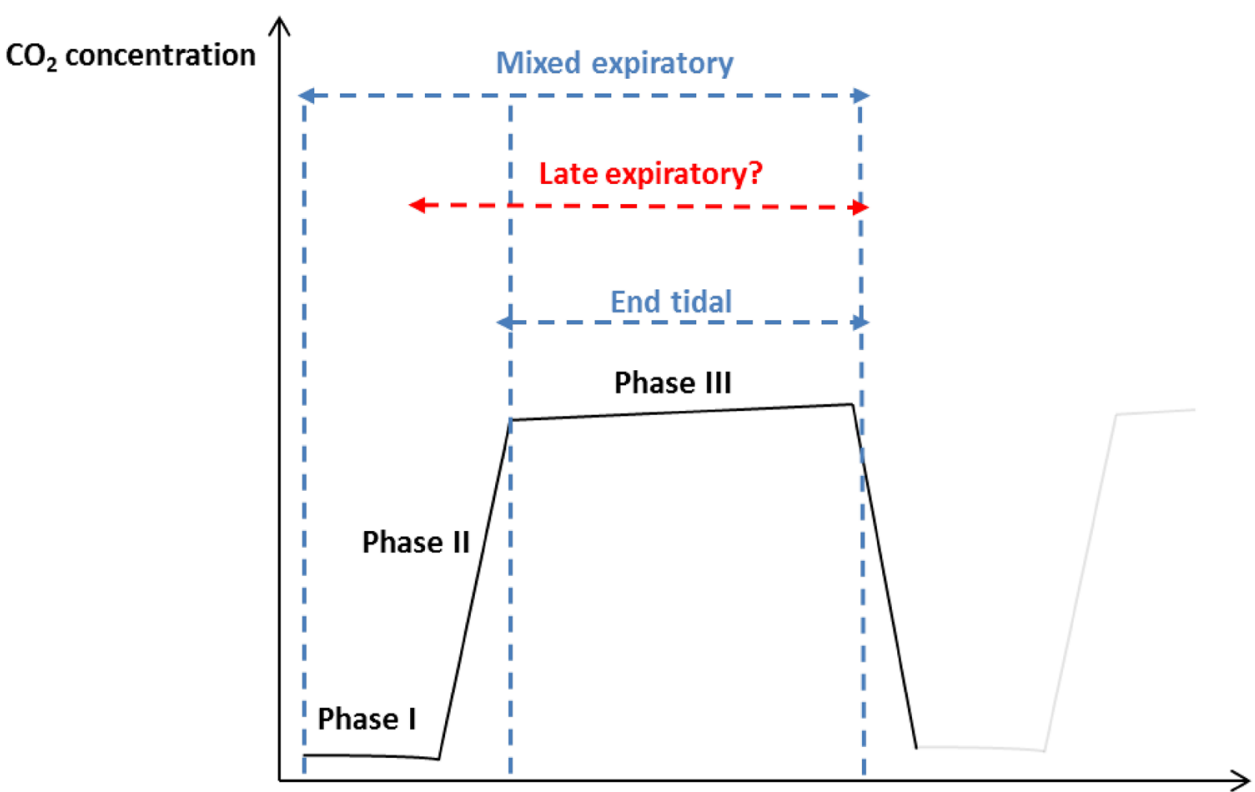

Time 
Table 1 Studies that collected late expiratory breath

\begin{tabular}{|c|c|c|c|}
\hline Brief description & Breath collection container & Pre-concentration method & Reference \\
\hline $\begin{array}{l}\text { Dead space air collected in one bag, } \\
\text { late expired air in separate bag }\end{array}$ & Tedlar bag & $\begin{array}{l}\text { TD tube-Multi-bed ORBO }{ }^{\mathrm{TM}} 420 / \\
\text { Tenax TA } \\
\text { TD tube-Tenax }\end{array}$ & $\begin{array}{l}\text { (Amal et al. 2016; Barash et al. } \\
\text { 2015; Gruber et al. 2014; Peled } \\
\text { et al. 2012; Xu et al. 2013) }\end{array}$ \\
\hline First $10 \mathrm{~s}$ excluded from bag & Tedlar bag & $\begin{array}{l}\text { TD tube-Carboxen 1000/Car- } \\
\text { bopack X/Carbopack B }\end{array}$ & (Sanchez and Sacks 2006) \\
\hline $\begin{array}{l}\text { Deep breath, held for } 10 \mathrm{~s} \text {, exhaled } \\
\text { slowly for } 10 \mathrm{~s} \text { prior to filling bag }\end{array}$ & Tedlar bag & $\begin{array}{l}\text { TD tube - Carbopack Y/B/X/Car- } \\
\text { boxen } 1000\end{array}$ & (Libardoni et al. 2006) \\
\hline $\begin{array}{l}\text { Exhale air into tube connected to } \\
\text { bag }\end{array}$ & Tedlar bag & TD tube-Tenax GC & (Preti et al. 1988) \\
\hline $\begin{array}{l}\text { Forced expiratory breath with first } \\
2-3 \text { s of expiration not collected }\end{array}$ & Tedlar bag & $\begin{array}{l}\text { In house sorbent microtrap- } \\
\text { Carboxen 1000, Carbopack X, } \\
\text { Carbopack B }\end{array}$ & (Castellanos et al. 2016) \\
\hline $\begin{array}{l}\text { Final portion of exhaled breath } \\
\text { collected }\end{array}$ & ALTEF polypropylene bag & TD tube-Tenax TA & (Harshman et al. 2015) \\
\hline $\begin{array}{l}\text { Last portion of breath collected } \\
\text { using ha-pause method }\end{array}$ & Aluminium gas bag & TD tube-Tenax TA/Unicarb & (Berna et al. 2015) \\
\hline $\begin{array}{l}\text { Second half of exhaled breath col- } \\
\text { lected }\end{array}$ & FlexFilm bag & TD tube-Tenax TA/Carbotrap B & (Bigazzi et al. 2016) \\
\hline $\begin{array}{l}\text { First third of each breath not col- } \\
\text { lected }\end{array}$ & Tedlar bag & SPME$-75 \mu \mathrm{M}$ CAR/PDMS & (Chen et al. 2016) \\
\hline $\begin{array}{l}\text { Dead space air collected in one bag, } \\
\text { late expired air in separate bag } \\
\text { Mixed expiratory }\end{array}$ & Tedlar bag & SPME$-75 \mu \mathrm{M}$ CAR/PDMS & (Capuano et al. 2015) \\
\hline $\begin{array}{l}\text { Dead space air collected in one bag, } \\
\text { late expired air in separate bag }\end{array}$ & Tedlar bag & $\begin{array}{l}\text { SPME-100 } \mu \mathrm{M} \text { PDMS, } 65 \mu \mathrm{M} \\
\text { PDMS/DVB }\end{array}$ & (Ma et al. 2014) \\
\hline $\begin{array}{l}\text { Last portion of exhaled breath } \\
\text { using breath collecting device }\end{array}$ & Tedlar bag & SPME $-100 \mu \mathrm{M}$ PDMS & (Wang et al. 2012) \\
\hline $\begin{array}{l}\text { Dead space air collected in one bag, } \\
\text { late expired air in separate bag }\end{array}$ & Tedlar bag & SPME_fiber not specified & (Santonico et al. 2012) \\
\hline $\begin{array}{l}\text { Dead space air collected in one bag, } \\
\text { late expired air in separate bag }\end{array}$ & Mylar bag & SPME—PDMS/DVB & $\begin{array}{l}\text { (Hakim et al. 2011) (Peng et al. } \\
\text { 2010) }\end{array}$ \\
\hline Last of exhaled breath $(150 \mathrm{~mL})$ & Bio-VOC & TD tube-Carbotrap 300 & (Das et al. 2014) \\
\hline $\begin{array}{l}\text { Deep breath and slowly exhale as } \\
\text { fully as possible }\end{array}$ & Bio-VOC & $\begin{array}{l}\text { TD tube-Carbograph 1TD/Car- } \\
\text { bopack X }\end{array}$ & (Phillips et al. 2014) \\
\hline $\begin{array}{l}\text { Retained last of exhaled breath } \\
\quad(\sim 100 \mathrm{~mL})\end{array}$ & Bio-VOC & TD tube-Tenax TA/Unicarb & (Zaric et al. 2014) \\
\hline $\begin{array}{l}\text { End of forced vital capacity col- } \\
\text { lected }\end{array}$ & Bio-VOC & $\begin{array}{l}\text { TD tube-Tenax TA/Graphitized } \\
\text { Carbon black/Carbonized } \\
\text { molecular sieve }\end{array}$ & (Jareno-Esteban et al. 2013) \\
\hline $\begin{array}{l}\text { Last portion of exhaled breath } \\
(\sim 150 \mathrm{~mL})\end{array}$ & Bio-VOC & TD tube-Tenax TA/Unicarb & (Dadamio et al. 2012) \\
\hline $\begin{array}{l}\text { Last } 150 \mathrm{~mL} \text { of single slow vital } \\
\text { capacity } \\
\text { Mouth air }\end{array}$ & Bio-VOC & TD tube-Tenax TA/Unicarb & (van den Velde et al. 2007) \\
\hline Exhale until lungs are empty & Bio-VOC & TD tube-sorbent not specified & (Henderson and Matthews 2002) \\
\hline $\begin{array}{l}\text { Blow deeply and slowly through } \\
\text { sampler }(150 \mathrm{~mL})\end{array}$ & Bio-VOC & SPME—75 $\mu \mathrm{M}$ CAR/PDMS & (Raninen et al. 2016) \\
\hline $\begin{array}{l}\text { Last } 150 \mathrm{~mL} \text { of single slow vital } \\
\text { capacity }\end{array}$ & Bio-VOC & $\begin{array}{l}\text { SPME_-75 } \mu \mathrm{M} \text { CAR/PDMS, } \\
65 \mu \mathrm{M} \text { PDMS/DVB }\end{array}$ & (Corradi et al. 2015) \\
\hline $\begin{array}{l}\text { Last portion of exhaled breath } \\
\qquad(100 \mathrm{~mL})\end{array}$ & Bio-VOC & SPME$-75 \mu \mathrm{M}$ CAR/PDMS & (Kramer et al. 2015) \\
\hline $\begin{array}{l}\text { Last } 150 \mathrm{~mL} \text { of single slow vital } \\
\text { capacity }\end{array}$ & Bio-VOC & SPME $-75 \mu \mathrm{M}$ CAR/PDMS & (Poli et al. 2008) \\
\hline
\end{tabular}


Table 1 (continued)

\begin{tabular}{|c|c|c|c|}
\hline Brief description & Breath collection container & Pre-concentration method & Reference \\
\hline $\begin{array}{l}\text { Exhale into tubular structure with } \\
\text { dead space air flowing down- } \\
\text { stream and air collected upstream }\end{array}$ & BCA & $\begin{array}{l}\text { TD tube-Carbotrap/Carbosieve } \\
\text { SIII }\end{array}$ & $\begin{array}{l}\text { (Zeliger et al. 2012) (Moretti et al. } \\
\text { 2004) (Phillips 1997) }\end{array}$ \\
\hline $\begin{array}{l}18 \mathrm{~mL} \text { of one single end-tidal exha- } \\
\text { lation portion }\end{array}$ & Gas-tight syringe, SPME vial & SPME $-75 \mu \mathrm{M}$ CAR/PDMS & (King et al. 2010) \\
\hline $\begin{array}{l}\text { Single exhalations with first } 750 \\
\text { mL discarded }\end{array}$ & Gas-tight syringe, glass vial & SPME—65 $\mu \mathrm{M}$ PDMS/DVB & (Svensson et al. 2007) \\
\hline $\begin{array}{l}\text { Take } 2-3 \text { deep breaths, inhale and } \\
\text { hold breath for } 10-15 \mathrm{~s} \text {, exhale } \\
\text { into glass tube and collect an } \\
\text { aliquot of end- expired air }\end{array}$ & Glass tube, aluminum tube & $\begin{array}{l}\text { SPME-100 } \mu \mathrm{M} \text { CAR/PDMS } \\
\text { TD tube-Tenax TA }\end{array}$ & (Prado et al. 2003) \\
\hline $\begin{array}{l}\text { Pressure sensors to estimate breath } \\
\text { phases }\end{array}$ & Face mask & $\begin{array}{l}\text { TD tube-Tenax TA/Carbograph } \\
\text { 1TD }\end{array}$ & $\begin{array}{l}\text { (Kang and Paul Thomas 2016) } \\
\text { (Turner et al. 2011) }\end{array}$ \\
\hline $\begin{array}{l}\text { Pressure sensors to estimate breath } \\
\text { phases }\end{array}$ & Face mask & TD tube-Tenax TA/Carbotrap & $\begin{array}{l}\text { (Basanta et al. 2010) (Ibrahim et al. } \\
\text { 2011) }\end{array}$ \\
\hline First portion of breath removed & $\begin{array}{l}\text { Breath device connected to } \\
\text { desorption tube }\end{array}$ & $\begin{array}{l}\text { TD tube-Carbopack B/Carbopack } \\
\text { C }\end{array}$ & (Khalid et al. 2013) \\
\hline $\begin{array}{l}\text { Collected } 1000 \mathrm{~mL} \text { after discarding } \\
\text { dead space }\end{array}$ & Glass container & TD tube-Tenax & (Mangler et al. 2012) \\
\hline $\begin{array}{l}\text { Two tidal volume ventilations, a } \\
\text { deep inspiration and slow exhala- } \\
\text { tion for } 10 \mathrm{~s} \text {, first } 3 \mathrm{~s} \text { discarded }\end{array}$ & Stainless steel canisters & Glass beads & (Minh et al. 2011) \\
\hline $\begin{array}{l}\text { Deep inspiration, } 5 \mathrm{~s} \text { breathhold, } \\
\text { slow and complete exhalation } \\
\text { over } 10 \mathrm{~s} \text {. First } 2 \mathrm{~s} \text { discarded }\end{array}$ & Electro-polished stainless steel & - & (Barker et al. 2006) \\
\hline
\end{tabular}

$B C A$ breath collection apparatus, $C A R$ carboxen, $D M S$ differential mobility spectrometry, $D V B$ divinylbenzene, $E C D$ electron capture detector, $F I D$ flame ionisation detector, $G C-M S$ gas chromatography-mass spectrometry, $P D M S$ polydimethylsiloxane, $T D$ thermal desorption, $T o f$ time of flight

\subsection{Late expiratory breath}

Late expiratory breath sampling involves discarding the initial portion of exhaled breath (estimated dead space) and the subsequent capture of air at the end of the breath cycle. This type of breath accounts for a large proportion of studies which is presented in Table 1 (Fig. 3a). Minimisation of dead space (Phase I in Fig. 2) sampling allows a greater relative contribution of endogenous VOCs in the resultant sample, as well as reduces the levels of exogenous VOCs. In some methods this simply mandates excluding the first few seconds of exhalation from an individual before the breath sample is collected (Castellanos et al. 2016; Sanchez and Sacks 2006). Others involve a subject breathing into a collection reservoir for the breath to flow downstream whilst the air that is close to the donor is collected and may not be as straightforward (Phillips 1997). Time-controlled breath samples have been shown to be unreliable (Miekisch et al. 2008) and also with various timings used in different studies, there is no known optimal exclusion time duration. Concerns regarding reproducibility also arise due to distinct physiological properties of individuals such as cardiac output and pulmonary ventilation which may also introduce unwanted variability even within individuals sampled repeatedly in different physiological states (Cope et al. 2004; Sukul et al. 2016). Other sources of variability which may contribute to a lack of reproducibility include breath holding and expiratory flow rate which may alter VOC concentrations (Dweik et al. 2011; Sukul et al. 2014). Thus, with several concerns associated with this type of breath, more effort is still required before it is suitable for use in the clinic. The ideal system would need to adapt to the current physiological state of each individual to collect a representative sample and minimise dead space contamination, but this would be at the cost of the simplicity and practicality of many current systems (Kwak et al. 2014; Martin et al. 2010). By contrast, the use of a pressure sensor which activates sampling during a predefined phase of expiration, as determined by individual's expiratory pressure curve, can be used as a personalised system for sampling (Basanta et al. 2010). It is highly engineered, bulky and complex but may be a more precise alternative.

\subsection{End-tidal or 'Alveolar' breath}

The term 'alveolar' should be used with caution. It is used to indicate air collected from the start to the end of phase III of the breath cycle (Fig. 2). This type of air is stated to 
Table 2 Studies that collected end-tidal or 'alveolar' breath

\begin{tabular}{|c|c|c|c|}
\hline Brief description & Breath collection container & Pre-concentration method & Reference \\
\hline $\begin{array}{l}\mathrm{CO}_{2} \text { visual control \& mixed } \\
\text { expiratory using plastic } \\
\text { straws }\end{array}$ & Tedlar bag & $\begin{array}{l}\text { TD tube-Tenax TA/Carboxen 569/ } \\
\text { Carboxen } 1000\end{array}$ & (Filipiak et al. 2014) \\
\hline $\mathrm{CO}_{2}$ visual control & Tedlar bag & TD tube-Tenax TA & (Grabowska-Polanowska et al. 2013) \\
\hline $\mathrm{CO}_{2}$ visual control & Nalophan bag & TD tube-Tenax GR & (Salvo et al. 2015) \\
\hline $\mathrm{CO}_{2}$ visual control & Tedlar bag & SPME—75 $\mu \mathrm{M}$ CAR/PDMS & (Mochalski et al. 2014) \\
\hline $\mathrm{CO}_{2}$ visual control & $\begin{array}{l}\text { Tedlar bag } \\
\text { Gas-tight syringe, glass vial }\end{array}$ & $\begin{array}{l}\text { SPME—PDMS, PDMS/DVB, PA, } \\
\text { CAR/PDMS, CW/DVB, DVB/CAR/ } \\
\text { PDMS } \\
\text { SPME—75 } \mu \mathrm{M} \text { CAR/PDMS }\end{array}$ & $\begin{array}{l}\text { (Bajtarevic et al. 2009; Buszewski et al. } \\
\text { 2009; Ligor et al. 2007; Ulanowska } \\
\text { et al. 2011; Ulanowska et al. 2012) }\end{array}$ \\
\hline $\mathrm{CO}_{2}$ visual control & $\begin{array}{l}\text { Tedlar bag } \\
\text { Gas-tight syringe, glass vial }\end{array}$ & $\mathrm{SPME}-\mathrm{CAR} / \mathrm{PDMS}$ & (Miekisch et al. 2008) \\
\hline $\mathrm{CO}_{2}$ visual control & Tedlar bag & $\begin{array}{l}\text { NTD_Tenax TA/Carbopack X/Car- } \\
\text { boxen } 1000\end{array}$ & (Mochalski et al. 2013) \\
\hline $\mathrm{CO}_{2}$ visual control & - & $\begin{array}{l}\text { NTD_Tenax TA/Carbopack X/Car- } \\
\text { boxen } 1000\end{array}$ & (Gruber et al. 2016) \\
\hline $\mathrm{CO}_{2}$ visual control & - & $\begin{array}{l}\text { NTD_Tenax TA/Carbopack X/Car- } \\
\text { boxen } 1000\end{array}$ & (Mieth et al. 2010) \\
\hline $\mathrm{CO}_{2}$ visual control & Gas-tight syringe, glass vial & SPME-75 $\mu \mathrm{M}$ CAR/PDMS & (Guo et al. 2015; Wang et al. 2014) \\
\hline $\mathrm{CO}_{2}$ visual control & Gas-tight syringe, glass vial & $\begin{array}{l}\text { SPME-CAR/PDMS } \\
\text { SPME-75 } \mu \mathrm{M} \text { CAR/PDMS } \\
\text { SPME-65 } \mu \mathrm{M} \text { PDMS/DVB }\end{array}$ & $\begin{array}{l}\text { (Fuchs et al. 2010; Goerl et al. 2013; } \\
\text { Kischkel et al. 2012; Pabst et al. 2007; } \\
\text { Schubert et al. 2005) }\end{array}$ \\
\hline Rebreathed air & Tedlar bag & Freeze-trap breath in glass U-tube & (Jones et al. 1983) \\
\hline$* \mathrm{CO}_{2}$ visual control & glass syringe & TD tube-Carbotrap B/Carbopack X & (Filipiak et al. 2015) \\
\hline
\end{tabular}

$C W$ carbowax, NTD needle trap device, asterisk (*) denotes ventilated patients

contain high concentrations of endogenous VOCs and minimal contaminants. However, using the term 'alveolar' may be misleading as gas exchange models have shown that VOC exchange with the airways may be occurring (Anderson et al. 2003; Anderson and Hlastala 2007) and thus may not completely reflect alveolar concentrations. Revised terminologies for this breath type include end-tidal, end-exhaled, and end-expired (Lourenco and Turner 2014); we use end-tidal in this article. This type of breath differs from late expiratory in terms of the confidence of obtaining a representative (and personalised) end-tidal sample, using a visual cue to collect air only from phase III.

In the articles reviewed, $\mathrm{CO}_{2}$ visual control accounts for the most common method (see 'Brief description' in Table 2) used to collect end-tidal breath and it involves monitoring $\mathrm{CO}_{2}$ concentrations during exhalation. During phase I of exhalation (Fig. 2), $\mathrm{CO}_{2}$ levels are generally low but rise during transition (phase II) and subsequently approaches a plateau signalling the start of alveolar phase III. Breath $\mathrm{CO}_{2}$ levels can be monitored via a device known as a capnometer that enables visualisation of the various phases for guidance on when to begin breath capture. There are devices which allow manual removal of air when alveolar phase has been reached (Miekisch et al. 2010, 2008) and also automatic capture (Salvo et al. 2015). The use of $\mathrm{CO}_{2}$ visual control breath sampling can also be extended to ventilated patients (Schubert et al. 2005).

Since a VOC profile of mostly endogenous sample is expected, there is a considerable likelihood of detecting potentially robust markers which decreases the chances of a type I error. Similarly to late expiratory breath, airway VOCs may be lost and as not all endogenous markers originate systemically, this breath type is not suited for investigating airway diseases. A well-known endogenous (non-organic) breath marker originating from the airways is nitric oxide which has been adopted in the clinic for the characterisation of asthma (Dweik et al. 2011). Since breath collection is adapted to each individual as samples are collected at phase III, variability regarding collection of samples is minimised and thus it would be more suitable for use in a clinic due to the availability of a benchmark. There are many steps before clinic adoption, but at least it might enable comparison of data between laboratories and studies.

Rebreathing is another proposed method for achieving an end-tidal breath sample. In this approach the aim is to achieve equilibrium between a container, the airways, and bloodstream as a subject breathes. There is usually no introduction of an external source of air during this process. It is postulated that the concentration in the container reflects a concentration close to blood concentration. A 
Table 3 Studies that collected mixed expiratory breath

\begin{tabular}{|c|c|c|c|}
\hline Brief description & Breath collection container & Pre-concentration method & Reference \\
\hline $\begin{array}{l}\text { Breathe through to face mask } \\
\text { Exhalation into bag } \\
\text { Inhale hold breath for } 5 \mathrm{~s} \text { and fully } \\
\text { expire }\end{array}$ & Tedlar bag & $\begin{array}{l}\text { TD tube-Carbograph 1TD/Car- } \\
\text { bopack X } \\
\text { TD tube-Carbon-filled }\end{array}$ & $\begin{array}{l}\text { (Pijls et al. 2016) (Smolinska et al. } \\
\text { 2014) (Baranska et al. 2013; Dal- } \\
\text { linga et al. 2010; Robroeks et al. } \\
\text { 2010; Van Berkel et al. 2010; } \\
\text { van de Kant et al. 2013; Verdam } \\
\text { et al. 2013) }\end{array}$ \\
\hline $\begin{array}{l}\text { Single vital capacity following } \\
\text { deep inspiration }\end{array}$ & Tedlar bag & $\begin{array}{l}\text { TD tube-Carboxen 1003/Car- } \\
\text { bopack B/Carbopack Y }\end{array}$ & (Altomare et al. 2013) \\
\hline Forced expiration & $\begin{array}{l}\text { Tedlar, Supel foil, Supel inert gas } \\
\text { sampling bags. Glass sampling } \\
\text { bulbs }\end{array}$ & $\begin{array}{l}\text { TD tube-Chromosorb106/Tenax } \\
\text { TA/Carbopack B } \\
\text { SPME-DVB/CAR/PDMS }\end{array}$ & (Scott-Thomas et al. 2013) \\
\hline Deep breath and exhale & Tedlar bag & $\begin{array}{l}\text { TD tube-Carboxen 1000/Car- } \\
\text { bopack X /Carbopack B }\end{array}$ & (Alonso et al. 2010) \\
\hline Spirometer used & Tedlar bag & TD tube-Tenax & (Gordon et al. 1988) \\
\hline $\begin{array}{l}\text { Inhale air to total lung capacity } \\
\text { and exhale into bag }\end{array}$ & Mylar bag & TD tube-sorbent not specified & (Machado et al. 2005) \\
\hline $\begin{array}{l}\text { Breathe moderately into bag after } \\
\text { initial washout period }\end{array}$ & Tedlar bag & SPME—75 $\mu \mathrm{M}$ CAR/PDMS & (Hyspler et al. 2000) \\
\hline $\begin{array}{l}\text { Inhale/exhale normally then } \\
\text { deeply exhale into bag after } 5 \mathrm{~s} \\
\text { holding breath }\end{array}$ & Tedlar bag & $\begin{array}{l}\text { SPME—50/30 } \mu \mathrm{M} \text { DVB/CAR/ } \\
\text { PDMS }\end{array}$ & (Caldeira et al. 2012) \\
\hline Deeply breathe into bag & Tedlar bag & SPME$-75 \mu \mathrm{M}$ CAR/PDMS & (Song et al. 2010) \\
\hline Breath collected using straw & Tedlar bag & SPME $-75 \mu \mathrm{M}$ CAR/PDMS & $\begin{array}{l}\text { (Bajtarevic et al. 2009; Ligor et al. } \\
\text { 2009) }\end{array}$ \\
\hline Exhale into bag via straw & Tedlar bag & SPME-CAR/PDMS & (Erhart et al. 2009) \\
\hline $\begin{array}{l}\text { Inhale moderately and exhale as } \\
\text { much as possible }\end{array}$ & Tedlar bag & SPME—PDMS/DVB & (Deng et al. 2004) \\
\hline $\begin{array}{l}\text { Expired into a bag via a rudolph } \\
\text { valve and delivery tube }\end{array}$ & Gas sampling bag & TD tube-Tenax GC & (Gordon et al. 1985) \\
\hline $\begin{array}{l}\text { Inspired/expired deeply } 3 \times \text {, } \\
\text { retained breath for } 20 \mathrm{~s} \text { and then } \\
\text { expired into container }\end{array}$ & Bio-VOC & TD tube-Tenax TA & (Marco and Grimalt 2015) \\
\hline $\begin{array}{l}\text { Breathe deeply through breath } \\
\text { collection container }\end{array}$ & $\begin{array}{l}\text { Bio-VOC, ALTEF polypropylene } \\
\text { bag }\end{array}$ & TD tube-Tenax TA & (Kwak et al. 2014) \\
\hline $\begin{array}{l}\text { Breathe at normal frequency } \\
\text { through RTube }\end{array}$ & RTube & SPME—65 $\mu \mathrm{M}$ PDMS/DVB & (Martin et al. 2010) \\
\hline $\begin{array}{l}\text { Deep inhalation and slow exhala- } \\
\text { tion through sampling device }\end{array}$ & Gas bulb & SPME $-75 \mu \mathrm{M}$ CAR/PDMS & (Schallschmidt et al. 2016) \\
\hline Forced expiration of five breaths & Gas bulb & SPME—DVB/CAR/PDMS & (Syhre et al. 2009) \\
\hline $\begin{array}{l}\text { Inhaled through a carbon filter and } \\
\text { exhaled into a reservoir }\end{array}$ & Stainless steel reservoir & TD tube-Tenax TA & (Gaida et al. 2016) \\
\hline Whole breath sample collected & Stainless steel canister & - & (Gordon et al. 2002) \\
\hline Mixed expiratory & $\begin{array}{l}\text { SUMMA passivated stainless } \\
\text { steel canisters }\end{array}$ & $\begin{array}{l}\text { Stainless steel tube with glass } \\
\text { beads }\end{array}$ & (Thomas et al. 1991) \\
\hline $\begin{array}{l}\text { Inhale (hold breath for } 10 \mathrm{~s} \text { ) and } \\
\text { forcefully expire }\end{array}$ & Glass tube & - & (Stein et al. 1996) \\
\hline $\begin{array}{l}15 \text { s Breath holding then exhala- } \\
\text { tion }\end{array}$ & $\begin{array}{l}\text { Polypropylene tubing, Gas-tight } \\
\text { syringe }\end{array}$ & Glass trap tube-Tenax GC & (Tangerman et al. 1983) \\
\hline Breath collected in bag & Tedlar bag & $\begin{array}{l}\text { SPME_CAR/PDMS, DVB/ } \\
\text { PDMS, PDMS, CAR/PDMS/ } \\
\text { DVB }\end{array}$ & (Garcia et al. 2014) \\
\hline Breath collected in bag & $\begin{array}{l}\text { Tedlar bag } \\
\text { Glass vial }\end{array}$ & SPME—75 $\mu \mathrm{M}$ CAR/PDMS & (Rudnicka et al. 2011) \\
\hline Breath collected in bag & Smart Bag PA & $\begin{array}{l}\text { NTD—Carbopack X and CMS } \\
\text { absorbent }\end{array}$ & (Ueta et al. 2014) \\
\hline
\end{tabular}




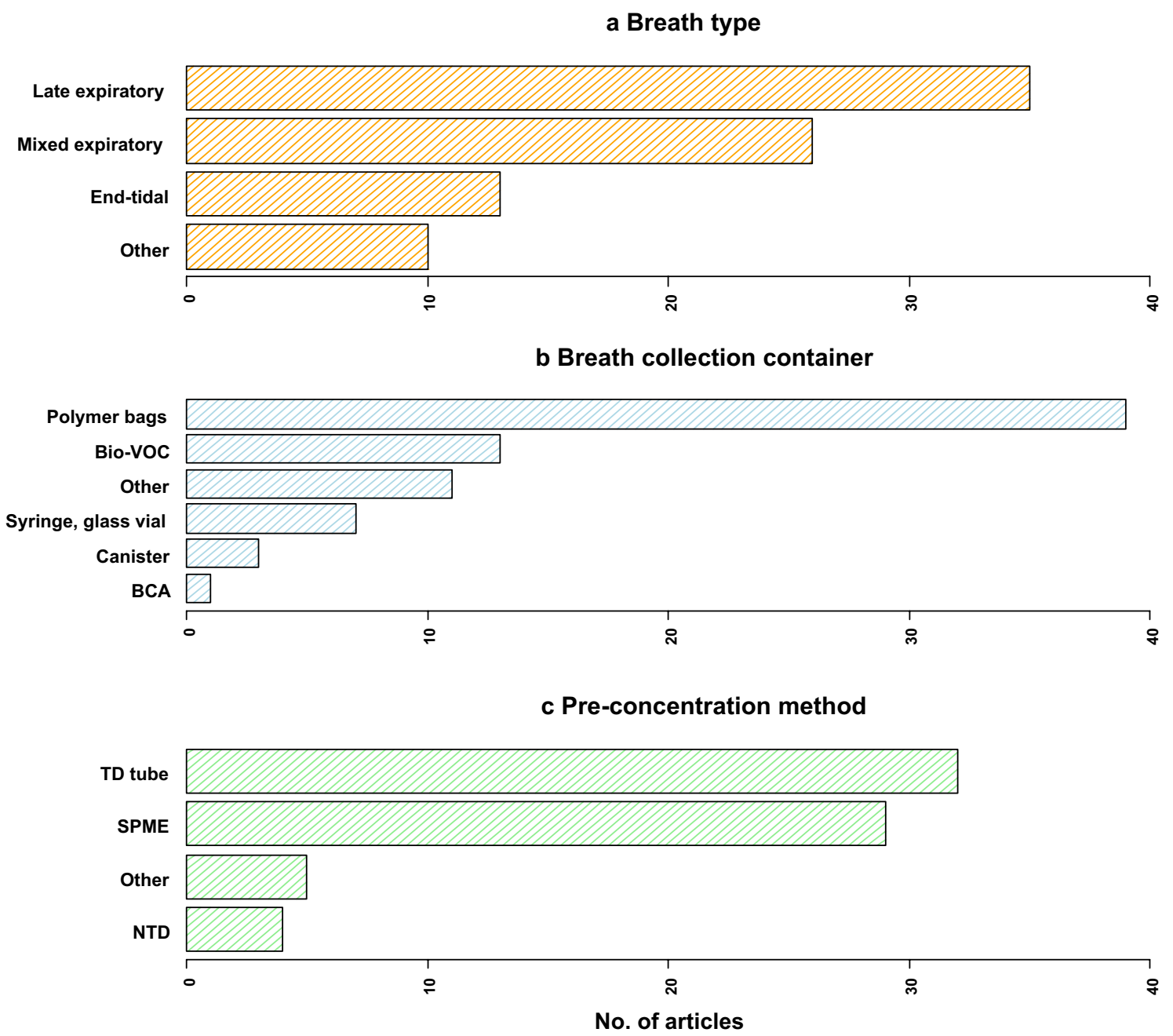

Fig. 3 Bar charts showing the percentage distribution of a breath types, $\mathbf{b}$ breath collection containers, $\mathbf{c}$ pre-concentration methods reviewed

comparable breath and blood ethanol concentration has been shown using this method (Jones 1983). However, this is for a single analyte and may not apply to all metabolites. A similar result was obtained by Ohlsson et al. using a variation of rebreathing known as isothermal rebreathing (Ohlsson et al. 1990). This variant aims to minimise condensation in the container and airways. A protocol for isothermal rebreathing has also been developed by (O'Hara et al. 2008). Visual representation of breath phases is absent and may not be necessary using this method as ambient air is not introduced after the first exhalation. This approach may not be suitable for clinic due to potential discomfort to patients; i.e., rising carbon dioxide levels and decreasing oxygen concentration, and would certainly not be appropriate for individuals with acute respiratory compromise (or in mechanically ventilated patients). Condensation may also impact on the stability of VOCs collected in this manner if not addressed.

\subsection{Mixed expiratory}

Mixed expiratory breath can be considered as the simplest type of breath that can be obtained since it involves acquiring all phases of air exhaled as depicted in Fig. 2. It may be an attractive option due to its simplicity, however, it may not provide the best quality of breath sample due to a greater abundance of environmental, mouth, and nose contaminants. Although there are feature selection models to aid in candidate biomarker selection, unless subject numbers are very large, there may still be a considerable chance of a false positive result in this situation; i.e., identifying an exogenous VOC as a candidate marker. This has been acknowledged by several studies highlighting the need for rigorous control and reproducible sampling when obtaining breath samples (Miekisch et al. 2008; O'Hara et al. 2008; Thekedar et al. 2011).

In summary, the ideal breath sampling method would be simple, tailored to personal physiology, allow targeted 
selection of airway and/or alveolar air (as appropriate to the disease under study), and eliminate sampling from the dead space and environment. This combination is not yet possible, and all current methods necessitate compromise in one or more areas. As breath analysis is currently still in its infancy, and the main aim is biomarker discovery, we would propose that compromises should be minimised (and simplicity in particular sacrificed).

\section{Breath collection containers}

Direct breath sampling onto pre-concentration materials is possible (Basanta et al. 2010), but a large proportion of the studies reviewed describe temporary storage prior to pre-concentration. The frequency of use for various storage containers is shown Fig. 3b. Polymer bags encompass the majority of breath collection containers; of which Tedlar ${ }^{\circledR}$ bags (E.I. du Pont de Nemours and Company, Wilmington, DE, USA) are the most commonly used. Other polymer bags include Mylar, and aluminium bags. Bio-VOC ${ }^{\text {TM }}$ Sampler (Markes International, Llantrisant, Wales, UK) (a late expiratory breath sampler), breath collection apparatus (BCA, Menssana Research Inc., Newark, NJ, USA), and glass vials (in combination with gas-tight syringes) have also been utilised for breath collection (Rattray et al. 2014). For clinical utility, the ideal collection container should be cost and user-friendly, durable, inert and importantly allow neither ingress of environmental nor egress of breath VOCs. It would also be compatible with multiple VOC trapping devices. As a case study, BCA and Bio-VOC ${ }^{\text {TM }}$ Sampler devices have the same aim of collecting late expiratory air. The structure and mechanism of collection already suggests potential differences in collected compounds; i.e., BCA is an extended tubular structure where air flows downstream and the air proximal to the mouth is collected. The Bio-VOC ${ }^{\text {TM }}$ Sampler is a small storage reservoir in which air is continuously displaced as exhalation proceeds. The aim of both devices is to capture breath sample that has a greater concentration of preferentially late-expiratory air. To limit condensation, the BCA has a heated component, whilst the Bio-VOC ${ }^{\text {TM }}$ Sampler does not and obtained VOC profiles may vary. Other factors such as background or contaminant levels of the container should be considered in order to prevent compromising valuable human samples. Standard guidelines that take into account background contaminants may be useful. The possible variability of the breath sample during storage should also be considered and documented, as it is known that Tedlar ${ }^{\circledR}$ bags absorb some constituents of breath during storage (Beauchamp et al. 2008).

\section{Pre-concentration methods}

Pre-concentration is often necessary in order to detect VOCs that are present in breath at ppmv and lower concentrations. For some collection methods, dilution of VOCs can occur and this is particularly the case for mixed expiratory breath samples. Commonly used pre-concentration methods include sorbent-containing thermal desorption (TD) tubes, the employment of solid phase microextraction (SPME), as well as needle trap devices (NTDs) and these are discussed below.

\subsection{Thermal desorption (TD) tubes}

TD tubes are popular for pre-concentrating VOCs and account for almost half of the pre-concentration methods published to date (Fig. 3c). Sorbents can be manually packed into the tubes or tubes can be purchased pre-packed from suppliers. Commonly used sorbents include Tenax TA \& GR, Carbograph 5TD, Carboxen. Due to the distinct properties of these materials there is important variability in the range of volatiles that can be trapped, as well as the stability of sorbent-compound interaction. Sample volume should be considered in order to prevent breakthrough and subsequent loss of analytes. Strong sorbents such as Carboxen are suitable for trapping very volatile organic compounds $\left(\sim \mathrm{C}_{2}-\mathrm{C}_{4}\right)$ while Tenax sorbents trap less volatile VOCs in breath $\left(\sim \mathrm{C}_{7}-\mathrm{C}_{15}\right)$ (Dettmer and Engewald 2002). Some factors that need to be considered include whether to use single or multi-bed sorbents which will depend on analytes of interest, and also the quantity of sorbent used. Whilst multi-bed sorbents can trap a larger range of different chemical species, both in terms of volatility but also polarity, analyte-sorbent interactions at the interfaces of the packed beds can affect reproducibility and thus compound recovery, and perhaps stability during storage (Kang and Paul Thomas 2016).

When breath has been temporarily stored in for example polymer bags, VOC-capture proceeds by attaching one end of the TD tube to the bag and the other end to a pump which functions to 'pull breath' from the bag across the sorbent. Whilst the use of these sorbent-containing TD tubes is stated to be highly sensitive, it can be quite time consuming. Also, sorbents like Carboxen are hydrophilic thus retain moisture which can negatively affect the quantitative capture of some analytes. Introducing a drypurging step especially when using a hydrophilic sorbent may be a solution (Gawlowski et al. 2000). Concerns such as the stability of VOCs trapped onto sorbent materials, storage and also logistics are apparent. It has been shown that these tubes can be stored for up to 2 weeks prior to analysis (Harshman et al. 2016; van der Schee et al. 2013) whilst another study suggests longer (Kang and Paul Thomas 2016). Samples collected using this method can 
be analysed in the laboratory present in hospitals provided that the required analytical platform is available which would require a significant investment. Alternatively, tubes can be temporarily stored and sent to laboratories off-site. Either way, this is readily adaptable for use in the clinic.

\subsection{Solid phase microextraction (SPME)}

SPME is a pre-concentration technique developed by Pawliszyn et al. which has found application for use in breath analysis (Grote and Pawliszyn 1997). It involves exposing a coated fused-silica fibre to the headspace of samples. Coating materials include amongst others polydimethylsiloxane (PDMS) and polyacrylate (PA). These coatings trap VOCs by absorption/adsorption mechanisms (Vas and Vekey 2004). Sampling is usually completed when equilibrium is established between the fibre and the sample which is stated to be fast in the case of volatile analytes. The time to equilibrium depends on several factors including fibre type, thickness, length, and agitation. Common combinations of SPME coatings, as tabulated in the pre-concentration summaries (Tables 1,2,3), include $75 \mu \mathrm{m} / 85 \mu \mathrm{m}$ CAR/PDMS for gases and low molecular weight compounds (MW 30-225), $100 \mu \mathrm{m}$ PDMS for volatiles (MW 60-275), $65 \mu \mathrm{m}$ PDMS/DVB for volatiles, amines, \& nitro-aromatic compounds (MW 50-300), $85 \mu \mathrm{m}$ PA for polar semi-volatiles (MW 80-300), $7 \mu \mathrm{m}$ PDMS for non-polar high molecular weight compounds (MW 125-600), $30 \mu \mathrm{m}$ PDMS for non-polar semi-volatiles, and $60 \mu \mathrm{m} \mathrm{CW}$ for alcohols and polar compounds (MW 40-275) (Sigma-Aldrich, Gillingham, UK). This method has been stated to have a comparable sensitivity to TD tubes but may be limited by the amount of coating and thickness of fibres (Vas and Vekey 2004).

\subsection{Needle trap devices (NTDs)}

NTDs are also utilised for the capture of analytes from exhaled breath. Briefly, sorbent materials are confined within a needle-like device and breath is 'pulled' through the needle to capture VOCs. The method aims to encompass the best features from SPME and TD tubes i.e. reduced sampling times while retaining adequate sensitivity (Lord et al. 2010). This method is discussed in detail elsewhere (Filipiak et al. 2012; Trefz et al. 2012, 2013). Similarly to TD tubes, sensitivity can be improved by increasing sampling volume (Trefz et al. 2013). Samples obtained using both SPME (Chai and Pawliszyn 1995; Grote and Pawliszyn 1997) and NTDs (Mieth et al. 2009) are reported to be stable for a couple of hours before significant losses are observed.

\section{Recommendations and future directions}

We have summarised the analytical pipelines that are commonly utilised for the off-line capture and pre-concentration of breath for VOC analysis. It is clear from this review that prior to conducting a breathomics study, the important sampling considerations include selection of the relevant breath fraction, the type of breath collecting container (if used), and pre-concentration technique.

From this literature survey we have seen that the methods of collecting late expiratory breath differs between studies and this may be due to an actual lack of proper definition and thus may be a contributing factor to the heterogeneous results which are reported (Dent et al. 2013; Phillips et al. 2003; Poli et al. 2005). Some studies associate the term 'alveolar' with their breath samples, and although in these studies the first few volumes of captured breath are discarded, this should be considered as late expiratory breath. We consider that breath samples collected under control, such as the $\mathrm{CO}_{2}$ monitoring method shown in Fig. 2 (i.e., from the start to end of phase III), may be described as 'alveolar' or end-tidal as the collection of the breath is bespoke to the person under analysis. This is not to suggest that late expiratory breath is not useful. On the contrary, as it does not use such complex $\mathrm{CO}_{2}$ monitoring, it does have the advantages such as ease of collection and it is also inexpensive and these deem it an attractive option. The aforementioned varied late expiratory definitions include different timings for exclusion of dead space air and the use of breath sampling manoeuvres such as breath holding and forced expirations which are stated to influence VOC content (Bikov et al. 2014; Dweik et al. 2011; Larstad et al. 2007; Thekedar et al. 2011) (see 'Brief description' in Table 1). This lack of uniformity most likely affects the reproducibility of acquired results. The goal of analysing the late expiratory breath is to capture a sample with a greater endogenous contribution. It would be more useful to obtain this type of sample with confidence using the controls that are available such as capnography or a set-defined late expiratory breath protocol. This is because this is specific to the individual, as each person will have a different breath profile due to size of their lungs, fitness and medication/disease.

Consistency with breath collection containers will also be important. A device having a heating component to prevent or minimise condensation effect and another without this property may culminate in the reporting of different results. Therefore adequate development and handling of these devices is required to maintain quality. Minimisation of condensation, removal of background contaminants and optimisation of storage time should be prioritised before use for studies. (Beauchamp et al. 2008); (Phillips 1997; Phillips et al. 2003). This should also be extended to preconcentration techniques. 
Herbig and Beauchamp suggested a framework for standardisation of reporting for breath sampling methods (Herbig and Beauchamp 2014), whereby the breath type and method of obtaining a breath type are reported to enable comparison between studies. That such standardisation is possible is showcased by the $\mathrm{HbA} 1 \mathrm{c}$ test for determining glucose levels in blood. Here also, similar reproducibility difficulties were experienced as a result of varying results across laboratories. This resulted in primary reference laboratories being established to work together nationally and then globally to deliver standardisation of this test (John et al. 2007). Only with cooperation between laboratories can the differences in breath type definition be fully explored and defined. Moreover, direct comparison of collection practices on a global scale will be required to establish a consensus on important parameters.

The need for breath sampling standardisation is stimulating engagement activity within the community as shown by a recent survey (Beauchamp 2015). Recently, a breath sampler was developed with input from a broad consortium of breath researchers and engineers which may aid in contributing to the sought after homogeneity in sampling within the breathomics community (http://www.breathefree.org). Finally, it is important to acknowledge that the collection of a certain type of breath should be linked to the clinical question under investigation.

\section{Summary and conclusion}

We have reviewed 110 articles describing various breath sampling methodologies and assessed them in terms of breath type collected, the containers used for collecting breath, and pre-concentration methods employed. It is clear from this research that the breath community need to converge in order to make improvements along the various steps of the breathomics analysis pipeline (as depicted in Fig. 1). We found that late expiratory breath is the most common breath type and is typically obtained based on crude estimations. These estimations of late expiratory breath are different in distinct studies and we suggest that standardisation of analysis protocols should be considered when acquiring this breath type. Breath sampling with the use of some form of guidance to provide confidence would certainly aid in improving the quality of the obtained sample. Focus on the clinical question may also help in determining the best type of breath sample to be collected.

We believe that improvement in quality along the various steps in the pipeline will aid in realising the translational potential of breath research from the laboratory and into the clinic.
Acknowledgements We are very grateful to the Centre for Information Science at Philips Research Eindhoven for conducting the STN search, and to all consortium partners within the EU FP7 project BreathDx and in particularly those involved within Philips Research and The University of Manchester. This work was funded by the European Union FP7 Marie Curie Actions, under the Industry-Academia Partnerships and Pathways (IAPP) programme (MC-IAPP BreathDx 611951).

\section{Compliance with Ethical Standards}

Conflict of interest All authors declare that they have no conflicts of interest.

Informed consent Informed consent was not required for this investigation.

Research involving human and animal studies This article does not contain any studies with human participants or animals performed by any of the authors.

Open Access This article is distributed under the terms of the Creative Commons Attribution 4.0 International License (http://creativecommons.org/licenses/by/4.0/), which permits unrestricted use, distribution, and reproduction in any medium, provided you give appropriate credit to the original author(s) and the source, provide a link to the Creative Commons license, and indicate if changes were made.

\section{References}

Alonso, M., Castellanos, M., \& Sanchez, J. M. (2010). Evaluation of potential breath biomarkers for active smoking: assessment of smoking habits. Analytical and Bioanalytical Chemistry, 396, 2987-2995.

Altomare, D. F., Di Lena, M., Porcelli, F., Trizio, L., Travaglio, E., Tutino, M., Dragonieri, S., Memeo, V., \& de Gennaro, G. (2013). Exhaled volatile organic compounds identify patients with colorectal cancer. British Journal of Surgery, 100, 144-150.

Amal, H., Leja, M., Funka, K., Lasina, I., Skapars, R., Sivins, A., Ancans, G., Kikuste, I., Vanags, A., Tolmanis, I., et al. (2016). Breath testing as potential colorectal cancer screening tool. International Journal of Cancer, 138, 229-236.

Anderson, J. C., Babb, A. L., \& Hlastala, M. P. (2003). Modeling soluble gas exchange in the airways and alveoli. Annals of Biomedical Engineering, 31, 1402-1422.

Anderson, J. C., \& Hlastala, M. P. (2007). Breath tests and airway gas exchange. Pulmonary Pharmacology \& Therapeutics, 20, $112-117$.

Bajtarevic, A., Ager, C., Pienz, M., Klieber, M., Schwarz, K., Ligor, M., Ligor, T., Filipiak, W., Denz, H., Fiegl, M., et al. (2009). Noninvasive detection of lung cancer by analysis of exhaled breath. BMC Cancer, 9, 348.

Baranska, A., Tigchelaar, E., Smolinska, A., Dallinga, J. W., Moonen, E. J., Dekens, J. A., Wijmenga, C., Zhernakova, A., \& van Schooten, F. J. (2013). Profile of volatile organic compounds in exhaled breath changes as a result of gluten-free diet. Journal of Breath Research, 7, 037104.

Barash, O., Zhang, W., Halpern, J. M., Hua, Q. L., Pan, Y. Y., Kayal, H., Khoury, K., Liu, H., Davies, M. P., \& Haick, H. (2015). Differentiation between genetic mutations of breast cancer by breath volatolomics. Oncotarget, 6, 44864. 
Barker, M., Hengst, M., Schmid, J., Buers, H. J., Mittermaier, B., Klemp, D., \& Koppmann, R. (2006). Volatile organic compounds in the exhaled breath of young patients with cystic fibrosis. The European Respiratory Journal, 27, 929-936.

Basanta, M., Jarvis, R. M., Xu, Y., Blackburn, G., Tal-Singer, R., Woodcock, A., Singh, D., Goodacre, R., Thomas, C.L.P., \& Fowler, S. J. (2010). Non-invasive metabolomic analysis of breath using differential mobility spectrometry in patients with chronic obstructive pulmonary disease and healthy smokers. The Analyst, 135, 315-320.

Beale, D. J., Jones, O. A., Karpe, A. V., Dayalan, S., Oh, D. Y., Kouremenos, K. A., Ahmed, W., \& Palombo, E. A. (2016). A Review of Analytical Techniques and Their Application in Disease Diagnosis in Breathomics and Salivaomics Research. International Journal of Molecular Sciences, 18, 24.

Beauchamp, J. (2015). Current sampling and analysis techniques in breath research-results of a task force poll. Journal of Breath Research, 9, 047107.

Beauchamp, J., Herbig, J., Gutmann, R., \& Hansel, A. (2008). On the use of Tedlar (R) bags for breath-gas sampling and analysis. Journal of Breath Research, 2, 046001.

Berna, A. Z., McCarthy, J. S., Wang, R. X., Saliba, K. J., Bravo, F. G., Cassells, J., Padovan, B., \& Trowell, S. C. (2015). Analysis of Breath Specimens for Biomarkers of Plasmodium falciparum Infection. The Journal of Infectious Diseases, 212, 1120-1128.

Bigazzi, A. Y., Figliozzi, M. A., Luo, W., \& Pankow, J. F. (2016). Breath Biomarkers to Measure Uptake of Volatile Organic Compounds by Bicyclists. Environmental Science \& Technology, 50, 5357-5363.

Bikov, A., Hernadi, M., Korosi, B. Z., Kunos, L., Zsamboki, G., Sutto, Z., Tarnoki, A. D., Tarnoki, D. L., Losonczy, G., \& Horvath, I. (2014). Expiratory flow rate, breath hold and anatomic dead space influence electronic nose ability to detect lung cancer. BMC Pulmonary Medicine, 14, 202.

Boots, A. W., Bos, L. D., van der Schee, M. P., van Schooten, F. J., \& Sterk, P. J. (2015). Exhaled molecular fingerprinting in diagnosis and monitoring: Validating volatile promises. Trends in Molecular Medicine, 21, 633-644.

Bos, L. D., Sterk, P. J., \& Schultz, M. J. (2013). Volatile metabolites of pathogens: a systematic review. PLoS Pathogens, 9, e1003311.

Buszewski, B., Ulanowska, A., Ligor, T., Denderz, N., \& Amann, A. (2009). Analysis of exhaled breath from smokers, passive smokers and non-smokers by solid-phase microextraction gas chromatography/mass spectrometry. Biomedical Chromatography, 23, 551-556.

Caldeira, M., Perestrelo, R., Barros, A. S., Bilelo, M. J., Morete, A., Camara, J. S., \& Rocha, S. M. (2012). Allergic asthma exhaled breath metabolome: A challenge for comprehensive two-dimensional gas chromatography. Journal of Chromatography A, 1254, 87-97.

Capuano, R., Santonico, M., Pennazza, G., Ghezzi, S., Martinelli, E., Roscioni, C., Lucantoni, G., Galluccio, G., Paolesse, R., Di Natale, C., et al (2015). The lung cancer breath signature: a comparative analysis of exhaled breath and air sampled from inside the lungs. Scientific Reports, 5, 16491.

Castellanos, M., Xifra, G., Fernandez-Real, J. M., \& Sanchez, J. M. (2016). Breath gas concentrations mirror exposure to sevoflurane and isopropyl alcohol in hospital environments in non-occupational conditions. Journal of Breath Research, 10, 016001.

Chai, M., \& Pawliszyn, J. (1995). Analysis of environmental air samples by solid-phase microextraction and gas chromatography/ion trap mass spectrometry. Environmental Science \& Technology, 29, 693-701.

Chen, Y., Zhang, Y., Pan, F., Liu, J., Wang, K., Zhang, C., Cheng, S., Lu, L., Zhang, W., Zhang, Z., et al. (2016). Breath analysis based on surface-enhanced raman scattering sensors distinguishes early and advanced gastric cancer patients from healthy persons. ACS Nano, 10, 8169-8179.

Cope, K.A., Watson, M.T., Foster, W.M., Sehnert, S.S., \& Risby, T.H. (2004). Effects of ventilation on the collection of exhaled breath in humans. J Appl Physiol (1985), 96, 1371-1379.

Corradi, M., Poli, D., Banda, I., Bonini, S., Mozzoni, P., Pinelli, S., Alinovi, R., Andreoli, R., Ampollini, L., Casalini, A., et al. (2015). Exhaled breath analysis in suspected cases of nonsmall-cell lung cancer: A cross-sectional study. Journal of Breath Research, 9, 027101.

Costello, B. D., Amann, A., Al-Kateb, H., Flynn, C., Filipiak, W., Khalid, T., Osborne, D., \& Ratcliffe, N. M. (2014). A review of the volatiles from the healthy human body. Journal of Breath Research, 8, 014001.

Dadamio, J., Van den Velde, S., Laleman, W., Van Hee, P., Coucke, W., Nevens, F., \& Quirynen, M. (2012). Breath biomarkers of liver cirrhosis. Journal of Chromatography B, 905, 17-22.

Dallinga, J. W., Robroeks, C. M., van Berkel, J. J., Moonen, E. J., Godschalk, R. W., Jobsis, Q., Dompeling, E., Wouters, E. F., \& van Schooten, F. J. (2010). Volatile organic compounds in exhaled breath as a diagnostic tool for asthma in children. Clinical \& Experimental Allergy, 40, 68-76.

Das, M. K., Bishwal, S. C., Das, A., Dabral, D., Varshney, A., Badireddy, V. K., \& Nanda, R. (2014). Investigation of genderspecific exhaled breath volatome in humans by GCxGC-TOFMS. Analytical Chemistry, 86, 1229-1237.

Deng, C., Zhang, J., Yu, X., Zhang, W., \& Zhang, X. (2004). Determination of acetone in human breath by gas chromatographymass spectrometry and solid-phase microextraction with on-fiber derivatization. Journal of Chromatography B, 810, 269-275.

Dent, A.G., Sutedja, T.G., \& Zimmerman, P.V. (2013). Exhaled breath analysis for lung cancer. Journal of Thoracic Disease, 5 Suppl 5, S540-S550.

Dettmer, K., \& Engewald, W. (2002). Adsorbent materials commonly used in air analysis for adsorptive enrichment and thermal desorption of volatile organic compounds. Analytical and Bioanalytical Chemistry, 373, 490-500.

Dweik, R. A., Boggs, P. B., Erzurum, S. C., Irvin, C. G., Leigh, M. W., Lundberg, J. O., Olin, A. C., Plummer, A. L., Taylor, D. R., \& Interpretat, A.T.S.C. (2011). An official ATS clinical practice guideline: interpretation of exhaled nitric oxide levels (FENO) for clinical applications. American Journal of Respiratory and Critical Care Medicine, 184, 602-615.

Erhart, S., Amann, A., Haberlandt, E., Edlinger, G., Schmid, A., Filipiak, W., Schwarz, K., Mochalski, P., Rostasy, K., Karall, D., et al. (2009). 3-Heptanone as a potential new marker for valproic acid therapy. Journal of Breath Research, 3, 016004.

Filipiak, W., Beer, R., Sponring, A., Filipiak, A., Ager, C., Schiefecker, A., Lanthaler, S., Helbok, R., Nagl, M., Troppmair, J., et al. (2015). Breath analysis for in vivo detection of pathogens related to ventilator-associated pneumonia in intensive care patients: a prospective pilot study. Journal of Breath Research, 9, 016004.

Filipiak, W., Filipiak, A., Ager, C., Wiesenhofer, H., \& Amann, A. (2012). Optimization of sampling parameters for collection and preconcentration of alveolar air by needle traps. Journal of Breath Research, 6, 027107.

Filipiak, W., Filipiak, A., Sponring, A., Schmid, T., Zelger, B., Ager, C., Klodzinska, E., Denz, H., Pizzini, A., Lucciarini, P., et al. (2014). Comparative analyses of volatile organic compounds (VOCs) from patients, tumors and transformed cell lines for the validation of lung cancer-derived breath markers. Journal of Breath Research, 8, 027111.

Fuchs, P., Loeseken, C., Schubert, J. K., \& Miekisch, W. (2010). Breath gas aldehydes as biomarkers of lung cancer. International Journal of Cancer, 126, 2663-2670. 
Gaida, A., Holz, O., Nell, C., Schuchardt, S., Lavae-Mokhtari, B., Kruse, L., Boas, U., Langejuergen, J., Allers, M., Zimmermann, S., et al. (2016). A dual center study to compare breath volatile organic compounds from smokers and non-smokers with and without COPD. Journal of Breath Research, 10, 026006 .

Garcia, R. A., Morales, V., Martin, S., Vilches, E., \& Toledano, A. (2014). Volatile organic compounds analysis in breath air in healthy volunteers and patients suffering epidermoid laryngeal carcinomas. Chromatographia, 77, 501-509.

Gawlowski, J., Gierczak, T., Pietruszynska, Z., Gawrys, M., \& Niedzielski, J. (2000). Dry purge for the removal of water from the solid sorbents used to sample volatile organic compounds from the atmospheric air. The Analyst, 125, 2112-2117.

Goerl, T., Kischkel, S., Sawacki, A., Fuchs, P., Miekisch, W., \& Schubert, J. K. (2013). Volatile breath biomarkers for patient monitoring during haemodialysis. Journal of Breath Research, 7, 017116.

Goodacre, R. (2007). Metabolomics of a superorganism. The Journal of Nutrition, 137, 259S-266S.

Gordon, S. M., Szidon, J. P., Krotoszynski, B. K., Gibbons, R. D., \& O'Neill, H. J. (1985). Volatile organic compounds in exhaled air from patients with lung cancer. Clinical Chemistry, 31, 1278-1282.

Gordon, S. M., Wallace, L. A., Brinkman, M. C., Callahan, P. J., \& Kenny, D. V. (2002). Volatile organic compounds as breath biomarkers for active and passive smoking. Environmental Health Perspectives, 110, 689-698.

Gordon, S. M., Wallace, L. A., Pellizzari, E. D., \& Oneill, H. J. (1988). Human breath measurements in a clean-air chamber to determine half-lives for volatile organic-compounds. Atmospheric Environment, 22, 2165-2170.

Grabowska-Polanowska, B., Faber, J., Skowron, M., Miarka, P., Pietrzycka, A., Sliwka, I., \& Amann, A. (2013). Detection of potential chronic kidney disease markers in breath using gas chromatography with mass-spectral detection coupled with thermal desorption method. Journal of Chromatography A, 1301, 179-189.

Grote, C., \& Pawliszyn, J. (1997). Solid-phase microextraction for the analysis of human breath. Analytical Chemistry, 69, 587-596.

Gruber, B., Keller, S., Groeger, T., Matuschek, G., Szymczak, W., \& Zimmermann, R. (2016). Breath gas monitoring during a glucose challenge by a combined PTR-QMS/GCxGC-TOFMS approach for the verification of potential volatile biomarkers. Journal of Breath Research, 10, 036003.

Gruber, M., Tisch, U., Jeries, R., Amal, H., Hakim, M., Ronen, O., Marshak, T., Zimmerman, D., Israel, O., Amiga, E., et al. (2014). Analysis of exhaled breath for diagnosing head and neck squamous cell carcinoma: a feasibility study. British Journal of Cancer, 111, 790-798.

Guo, L., Wang, C., Chi, C., Wang, X., Liu, S., Zhao, W., Ke, C., Xu, G., \& Li, E. (2015). Exhaled breath volatile biomarker analysis for thyroid cancer. Translational Research, 166, 188-195.

Hakim, M., Billan, S., Tisch, U., Peng, G., Dvrokind, I., Marom, O., Abdah-Bortnyak, R., Kuten, A., \& Haick, H. (2011). Diagnosis of head-and-neck cancer from exhaled breath. British Journal of Cancer, 104, 1649-1655.

Harshman, S. W., Geier, B. A., Fan, M., Rinehardt, S., Watts, B. S., Drummond, L. A., Preti, G., Phillips, J. B., Ott, D. K., \& Grigsby, C. C. (2015). The identification of hypoxia biomarkers from exhaled breath under normobaric conditions. Journal of Breath Research, 9, 047103

Harshman, S. W., Mani, N., Geier, B. A., Kwak, J., Shepard, P., Fan, M., Sudberry, G. L., Mayes, R. S., Ott, D. K., Martin, J. A., et al. (2016). Storage stability of exhaled breath on Tenax TA. Journal of Breath Research, 10, 046008.
Henderson, K. A., \& Matthews, I. P. (2002). Biological monitoring of midwives' exposure to $\mathrm{N}(2) \mathrm{O}$ using the Bio-VOC breath sampler. Journal of Exposure Science and Environmental Epidemiology, 12, 309-312.

Herbig, J., \& Beauchamp, J. (2014). Towards standardization in the analysis of breath gas volatiles. Journal of Breath Research, 8 , 037101 .

Hyspler, R., Crhova, S., Gasparic, J., Zadak, Z., Cizkova, M., \& Balasova, V. (2000). Determination of isoprene in human expired breath using solid-phase microextraction and gas chromatography-mass spectrometry. Journal of Chromatography B, 739, 183-190.

Ibrahim, B., Basanta, M., Cadden, P., Singh, D., Douce, D., Woodcock, A., \& Fowler, S. J. (2011). Non-invasive phenotyping using exhaled volatile organic compounds in asthma. Thorax, 66, 804-809.

Jareno-Esteban, J. J., Munoz-Lucas, M. A., Carrillo-Aranda, B., Maldonado-Sanz, J. A., de Granda-Orive, I., Aguilar-Ros, A., CiveraTejuca, C., Gutierrez-Ortega, C., Callol-Sanchez, L. M., \& Study, G. (2013). Volatile organic compounds in exhaled breath in a healthy population: effect of tobacco smoking. Archivos de Bronconeumologia, 49, 457-461.

John, W. G., Mosca, A., Weykamp, C., \& Goodall, I. (2007). HbA1c standardisation: History, science and politics. The Clinical Biochemist Reviews, 28, 163-168.

Jones, A. W. (1983). Role of rebreathing in determination of the bloodbreath ratio of expired ethanol. Journal of Applied Physiology, $55,1237-1241$

Jones, A.W., Mardh, G., \& Anggard, E. (1983). Determination of endogenous ethanol in blood and breath by gas chromatographymass spectrometry. Pharmacology Biochemistry and Behavior, 18 Suppl 1, 267-272.

Kang, S., \& Paul Thomas, C. L. (2016). How long may a breath sample be stored for at -80 degrees $C$ ? A study of the stability of volatile organic compounds trapped onto a mixed Tenax:Carbograph trap adsorbent bed from exhaled breath. Journal of Breath Research, 10, 026011.

Khalid, T. Y., Costello, B., Ewen, R., White, P., Stevens, S., Gordon, F., Collins, P., McCune, A., Shenoy, A., Shetty, S., et al. (2013). Breath volatile analysis from patients diagnosed with harmful drinking, cirrhosis and hepatic encephalopathy: A pilot study. Metabolomics, 9, 938-948.

King, J., Mochalski, P., Kupferthaler, A., Unterkofler, K., Koc, H., Filipiak, W., Teschl, S., Hinterhuber, H., \& Amann, A. (2010). Dynamic profiles of volatile organic compounds in exhaled breath as determined by a coupled PTR-MS/GC-MS study. Physiological Measurement, 31, 1169-1184.

Kischkel, S., Miekisch, W., Fuchs, P., \& Schubert, J. K. (2012). Breath analysis during one-lung ventilation in cancer patients. European Respiratory Journal, 40, 706-713.

Kramer, R., Sauer-Heilborn, A., Welte, T., Guzman, C. A., Hofle, M. G., \& Abraham, W. R. (2015). A rapid method for breath analysis in cystic fibrosis patients. European Journal of Clinical Microbiology \& Infectious Diseases, 34, 745-751.

Kwak, J., Fan, M., Harshman, S. W., Garrison, C. E., Dershem, V. L., Phillips, J. B., Grigsby, C. C., \& Ott, D. K. (2014). Evaluation of bio-VOC sampler for analysis of volatile organic compounds in exhaled breath. Metabolites, 4, 879-888.

Larstad, M. A., Toren, K., Bake, B., \& Olin, A. C. (2007). Determination of ethane, pentane and isoprene in exhaled air-effects of breath-holding, flow rate and purified air. Acta Physiologica, 189, 87-98.

Libardoni, M., Stevens, P. T., Waite, J. H., \& Sacks, R. (2006). Analysis of human breath samples with a multi-bed sorption trap and comprehensive two-dimensional gas chromatography (GC×GC). Journal of Chromatography B, 842, 13-21. 
Ligor, M., Ligor, T., Bajtarevic, A., Ager, C., Pienz, M., Klieber, M., Denz, H., Fiegl, M., Hilbe, W., Weiss, W., et al. (2009). Determination of volatile organic compounds in exhaled breath of patients with lung cancer using solid phase microextraction \& gas chromatography mass spectrometry. Clinical Chemistry and Laboratory Medicine, 47, 550-560.

Ligor, T., Szeliga, J., Jackowski, M., \& Buszewski, B. (2007). Preliminary study of volatile organic compounds from breath and stomach tissue by means of solid phase microextraction and gas chromatography-mass spectrometry. Journal of Breath Research, 1,016001 .

Lord, H. L., Zhan, W. Q., \& Pawliszyn, J. (2010). Fundamentals and applications of needle trap devices A critical review. Analytica Chimica Acta, 677, 3-18.

Lourenco, C., \& Turner, C. (2014). Breath analysis in disease diagnosis: methodological considerations and applications. Metabolites, $4,465-498$.

Ma, H. Y., Li, X., Chen, J. M., Wang, H. J., Cheng, T. T., Chen, K., $\&$ Xu, S. F. (2014). Analysis of human breath samples of lung cancer patients and healthy controls with solid-phase microextraction (SPME) and flow-modulated comprehensive two-dimensional gas chromatography (GC x GC). Analytical Methods, 6, 6841-6849.

Machado, R. F., Laskowski, D., Deffenderfer, O., Burch, T., Zheng, S., Mazzone, P. J., Mekhail, T., Jennings, C., Stoller, J. K., Pyle, J., et al. (2005). Detection of lung cancer by sensor array analyses of exhaled breath. American Journal of Respiratory and Critical Care Medicine, 171, 1286-1291.

Mangler, M., Freitag, C., Lanowska, M., Staeck, O., Schneider, A., $\&$ Speiser, D. (2012). Volatile organic compounds (VOCs) in exhaled breath of patients with breast cancer in a clinical setting. Ginekologia Polska, 83, 730-736.

Marco, E., \& Grimalt, J. O. (2015). A rapid method for the chromatographic analysis of volatile organic compounds in exhaled breath of tobacco cigarette and electronic cigarette smokers. Journal of Chromatography A, 1410, 51-59.

Martin, A. N., Farquar, G. R., Jones, A. D., \& Frank, M. (2010). Human breath analysis: methods for sample collection and reduction of localized background effects. Analytical and Bioanalytical Chemistry, 396, 739-750.

Miekisch, W., Hengstenberg, A., Kischkel, S., Beckmann, U., Mieth, M., \& Schubert, J. K. (2010). Construction and evaluation of a versatile co2 controlled breath collection device. IEEE Sensors Journal, 10, 211-215.

Miekisch, W., Kischkel, S., Sawacki, A., Liebau, T., Mieth, M., \& Schubert, J. K. (2008). Impact of sampling procedures on the results of breath analysis. Journal of Breath Research, 2, 026007.

Mieth, M., Kischkel, S., Schubert, J. K., Hein, D., \& Miekisch, W. (2009). Multibed needle trap devices for on site sampling and preconcentration of volatile breath biomarkers. Analytical Chemistry, 81, 5851-5857.

Mieth, M., Schubert, J. K., Groger, T., Sabel, B., Kischkel, S., Fuchs, P., Hein, D., Zimmermann, R., \& Miekisch, W. (2010). Automated needle trap heart-cut GC/MS and needle trap comprehensive two-dimensional GC/TOF-MS for breath gas analysis in the clinical environment. Analytical Chemistry, 82, 2541-2551.

Minh, T. D., Oliver, S. R., Ngo, J., Flores, R., Midyett, J., Meinardi, S., Carlson, M. K., Rowland, F. S., Blake, D. R., \& Galassetti, P. R. (2011). Noninvasive measurement of plasma glucose from exhaled breath in healthy and type 1 diabetic subjects. American Journal of Physiology-Endocrinology and Metabolism, 300, E1166-E1175.

Mochalski, P., King, J., Haas, M., Unterkofler, K., Amann, A., \& Mayer, G. (2014). Blood and breath profiles of volatile organic compounds in patients with end-stage renal disease. BMC Nephrology, 15,43 .
Mochalski, P., King, J., Klieber, M., Unterkofler, K., Hinterhuber, H., Baumann, M., \& Amann, A. (2013). Blood and breath levels of selected volatile organic compounds in healthy volunteers. The Analyst, 138, 2134-2145.

Moretti, M., Phillips, M., Abouzeid, A., Cataneo, R. N., \& Greenberg, J. (2004). Increased breath markers of oxidative stress in normal pregnancy and in preeclampsia. American Journal of Obstetrics and Gynecology, 190, 1184-1190.

O'Hara, M. E., O’Hehir, S., Green, S., \& Mayhew, C. A. (2008). Development of a protocol to measure volatile organic compounds in human breath: a comparison of rebreathing and on-line single exhalations using proton transfer reaction mass spectrometry. Physiological Measurement, 29, 309-330.

Ohlsson, J., Ralph, D. D., Mandelkorn, M. A., Babb, A. L., \& Hlastala, M. P. (1990). Accurate measurement of blood alcohol concentration with isothermal rebreathing. Journal of Studies on Alcohol, 51, 6-13.

Pabst, F., Miekisch, W., Fuchs, P., Kischkel, S., \& Schubert, J. K. (2007). Monitoring of oxidative and metabolic stress during cardiac surgery by means of breath biomarkers: an observational study. Journal of Cardiothoracic Surgery, 2, 37.

Peled, N., Hakim, M., Bunn, P. A. Jr., Miller, Y. E., Kennedy, T. C., Mattei, J., Mitchell, J. D., Hirsch, F. R., \& Haick, H. (2012). Non-invasive breath analysis of pulmonary nodules. Journal of Thoracic Oncology, 7, 1528-1533.

Peng, G., Hakim, M., Broza, Y. Y., Billan, S., Abdah-Bortnyak, R., Kuten, A., Tisch, U., \& Haick, H. (2010). Detection of lung, breast, colorectal, and prostate cancers from exhaled breath using a single array of nanosensors. British Journal of Cancer, 103, 542-551.

Phillips, C., Mac Parthalain, N., Syed, Y., Deganello, D., Claypole, T., \& Lewis, K. (2014). Short-term intra-subject variation in exhaled volatile organic compounds (VOCs) in COPD patients and healthy controls and its effect on disease classification. Metabolites, 4, 300-318.

Phillips, M. (1992). Breath Tests in Medicine. Scientific American, 267, 74-79.

Phillips, M. (1997). Method for the collection and assay of volatile organic compounds in breath. Analytical Biochemistry, 247, 272-278.

Phillips, M., Cataneo, R. N., Cummin, A. R., Gagliardi, A. J., Gleeson, K., Greenberg, J., Maxfield, R. A., \& Rom, W. N. (2003). Detection of lung cancer with volatile markers in the breath. Chest, 123, 2115-2123.

Pijls, K. E., Smolinska, A., Jonkers, D. M., Dallinga, J. W., Masclee, A. A., Koek, G. H., \& van Schooten, F. J. (2016). A profile of volatile organic compounds in exhaled air as a potential non-invasive biomarker for liver cirrhosis. Scientific Reports, 6, 19903.

Poli, D., Carbognani, P., Corradi, M., Goldoni, M., Acampa, O., Balbi, B., Bianchi, L., Rusca, M., \& Mutti, A. (2005). Exhaled volatile organic compounds in patients with non-small cell lung cancer: cross sectional and nested short-term follow-up study. Respiratory Research, 6, 71 .

Poli, D., Goldoni, M., Caglieri, A., Ceresa, G., Acampa, O., Carbognani, P., Rusca, M., \& Corradi, M. (2008). Breath analysis in non small cell lung cancer patients after surgical tumour resection. Acta Biomedica, 79 Suppl 1, 64-72.

Prado, C., Marin, P., \& Periago, J. F. (2003). Application of solid-phase microextraction and gas chromatography-mass spectrometry to the determination of volatile organic compounds in end-exhaled breath samples. Journal of chromatography A, 1011, 125-134.

Preti, G., Labows, J. N., Kostelc, J. G., Aldinger, S., \& Daniele, R. (1988). Analysis of lung air from patients with bronchogenic carcinoma and controls using gas chromatography-mass spectrometry. Journal of Chromatography B, 432, 1-11. 
Raninen, K. J., Lappi, J. E., Mukkala, M. L., Tuomainen, T. P., Mykkanen, H. M., Poutanen, K. S., \& Raatikainen, O. J. (2016). Fiber content of diet affects exhaled breath volatiles in fasting and postprandial state in a pilot crossover study. Nutrition Research, 36, 612-619.

Rattray, N. J., Hamrang, Z., Trivedi, D. K., Goodacre, R., \& Fowler, S. J. (2014). Taking your breath away: metabolomics breathes life in to personalized medicine. Trends in Biotechnology, 32, $538-548$.

Robroeks, C. M., van Berkel, J. J., Dallinga, J. W., Jobsis, Q., Zimmermann, L. J., Hendriks, H. J., Wouters, M. F., van der Grinten, C. P., van de Kant, K. D., van Schooten, F. J., et al. (2010). Metabolomics of volatile organic compounds in cystic fibrosis patients and controls. Pediatric Research, 68, 75-80.

Rudnicka, J., Kowalkowski, T., Ligor, T., \& Buszewski, B. (2011). Determination of volatile organic compounds as biomarkers of lung cancer by SPME-GC-TOF/MS and chemometrics. Journal of Chromatography B, 879, 3360-3366.

Salvo, P., Ferrari, C., Persia, R., Ghimenti, S., Lomonaco, T., Bellagambi, F., \& Di Francesco, F. (2015). A dual mode breath sampler for the collection of the end-tidal and dead space fractions. Medical Engineering \& Physics, 37, 539-544.

Sanchez, J. M., \& Sacks, R. D. (2006). Development of a multibed sorption trap, comprehensive two-dimensional gas chromatography, and time-of-flight mass spectrometry system for the analysis of volatile organic compounds in human breath. Analytical Chemistry, 78, 3046-3054.

Santonico, M., Lucantoni, G., Pennazza, G., Capuano, R., Galluccio, G., Roscioni, C., La Delfa, G., Consoli, D., Martinelli, E., Paolesse, R., et al (2012). In situ detection Of lung cancer volatile fingerprints using bronchoscopic air-sampling. Lung Cancer, 77, 46-50.

Schallschmidt, K., Becker, R., Jung, C., Bremser, W., Walles, T., Neudecker, J., Leschber, G., Frese, S., \& Nehls, I. (2016). Comparison of volatile organic compounds from lung cancer patients and healthy controls-challenges and limitations of an observational study. Journal of Breath Research, 10, 046007.

Schubert, J. K., Miekisch, W., Birken, T., Geiger, K., \& Noldge-Schomburg, G. F. (2005). Impact of inspired substance concentrations on the results of breath analysis in mechanically ventilated patients. Biomarkers, 10, 138-152.

Schulz, S., \& Dickschat, J. S. (2007). Bacterial volatiles: the smell of small organisms. Natural Product Reports, 24, 814-842.

Scott-Thomas, A., Epton, M., \& Chambers, S. (2013). Validating a breath collection and analysis system for the new tuberculosis breath test. Journal of Breath Research, 7, 037108.

Smolinska, A., Klaassen, E. M., Dallinga, J. W., van de Kant, K. D., Jobsis, Q., Moonen, E. J., van Schayck, O. C., Dompeling, E., \& van Schooten, F. J. (2014). Profiling of volatile organic compounds in exhaled breath as a strategy to find early predictive signatures of asthma in children. PLoS ONE, 9, e95668.

Song, G., Qin, T., Liu, H., Xu, G. B., Pan, Y. Y., Xiong, F. X., Gu, K. S., Sun, G. P., \& Chen, Z. D. (2010). Quantitative breath analysis of volatile organic compounds of lung cancer patients. Lung cancer (Amsterdam, Netherlands), 67, 227-231.

Stein, V. B., Narang, R. S., Wilson, L., \& Aldous, K. M. (1996). A simple, reliable method for the determination of chlorinated volatile organics in human breath and air using glass sampling tubes. Journal of Analytical Toxicology, 20, 145-150.

Sukul, P., Schubert, J. K., Oertel, P., Kamysek, S., Taunk, K., Trefz, P., \& Miekisch, W. (2016). FEV manoeuvre induced changes in breath VOC compositions: An unconventional view on lung function tests. Scientific Reports, 6, 28029.

Sukul, P., Trefz, P., Schubert, J. K., \& Miekisch, W. (2014). Immediate effects of breath holding maneuvers onto composition of exhaled breath. Journal of Breath Research, 8, 037102.
Svensson, S., Larstad, M., Broo, K., \& Olin, A. C. (2007). Determination of aldehydes in human breath by on-fibre derivatization, solid-phase microextraction and GC-MS. Journal of Chromatography $B, 860,86-91$.

Syhre, M., Manning, L., Phuanukoonnon, S., Harino, P., \& Chambers, S. T. (2009). The scent of Mycobacterium tuberculosis-part II breath. Tuberculosis, 89, 263-266.

Tangerman, A., Meuwese-Arends, M. T., \& van Tongeren, J. H. (1983). A new sensitive assay for measuring volatile sulphur compounds in human breath by Tenax trapping and gas chromatography and its application in liver cirrhosis. Clinica Chimica Acta, 130, 103-110.

Thekedar, B., Oeh, U., Szymczak, W., Hoeschen, C., \& Paretzke, H. G. (2011). Influences of mixed expiratory sampling parameters on exhaled volatile organic compound concentrations. Journal of Breath Research, 5, 016001.

Thomas, K. W., Pellizzari, E. D., \& Cooper, S. D. (1991). A canister-based method for collection and GC/MS analysis of volatile organic compounds in human breath. Journal of Analytical Toxicology, 15, 54-59.

Trefz, P., Kischkel, S., Hein, D., James, E. S., Schubert, J. K., \& Miekisch, W. (2012). Needle trap micro-extraction for VOC analysis: effects of packing materials and desorption parameters. Journal of Chromatography A, 1219, 29-38.

Trefz, P., Rosner, L., Hein, D., Schubert, J. K., \& Miekisch, W. (2013). Evaluation of needle trap micro-extraction and automatic alveolar sampling for point-of-care breath analysis. Analytical and Bioanalytical Chemistry, 405, 5617-5617.

Turner, M. A., Guallar-Hoyas, C., Kent, A. L., Wilson, I. D., \& Thomas, C. L. (2011). Comparison of metabolomic profiles obtained using chemical ionization and electron ionization MS in exhaled breath. Bioanalysis, 3, 2731-2738.

Ueta, I., Mizuguchi, A., Okamoto, M., Sakamaki, H., Hosoe, M., Ishiguro, M., \& Saito, Y. (2014). Determination of breath isoprene and acetone concentration with a needle-type extraction device in gas chromatography-mass spectrometry. Clinica Chimica Acta, $430,156-159$.

Ulanowska, A., Kowalkowski, T., Hrynkiewicz, K., Jackowski, M., \& Buszewski, B. (2011). Determination of volatile organic compounds in human breath for Helicobacter pylori detection by SPME-GC/MS. Biomedical Chromatography, 25, 391-397.

Ulanowska, A., Trawinska, E., Sawrycki, P., \& Buszewski, B. (2012). Chemotherapy control by breath profile with application of SPME-GC/MS method. Journal of Separation Science, 35, 2908-2913.

Van Berkel, J. J., Dallinga, J. W., Moller, G. M., Godschalk, R. W., Moonen, E. J., Wouters, E. F., \& Van Schooten, F. J. (2010). A profile of volatile organic compounds in breath discriminates COPD patients from controls. Respiratory Medicine, 104, $557-563$.

van de Kant, K. D., van Berkel, J. J., Jobsis, Q., Lima Passos, V., Klaassen, E. M., van der Sande, L., van Schayck, O. C., de Jongste, J. C., van Schooten, F. J., Derks, E., et al. (2013). Exhaled breath profiling in diagnosing wheezy preschool children. The European Respiratory Journal, 41, 183-188.

van den Velde, S., Quirynen, M., van Hee, P., \& van Steenberghe, D. (2007). Halitosis associated volatiles in breath of healthy subjects. Journal of Chromatography B, 853, 54-61.

van der Schee, M. P., Fens, N., Brinkman, P., Bos, L. D., Angelo, M. D., Nijsen, T. M., Raabe, R., Knobel, H. H., Vink, T. J., \& Sterk, P. J. (2013). Effect of transportation and storage using sorbent tubes of exhaled breath samples on diagnostic accuracy of electronic nose analysis. Journal of Breath Research, 7, 016002.

Vas, G., \& Vekey, K. (2004). Solid-phase microextraction: a powerful sample preparation tool prior to mass spectrometric analysis. Journal of Mass Spectrometry, 39, 233-254. 
Verdam, F. J., Dallinga, J. W., Driessen, A., de Jonge, C., Moonen, E. J., van Berkel, J. B., Luijk, J., Bouvy, N. D., Buurman, W. A., Rensen, S. S., et al. (2013). Non-alcoholic steatohepatitis: a non-invasive diagnosis by analysis of exhaled breath. Journal of Hepatology, 58, 543-548.

Wang, C., Ke, C., Wang, X., Chi, C., Guo, L., Luo, S., Guo, Z., Xu, G., Zhang, F., \& Li, E. (2014). Noninvasive detection of colorectal cancer by analysis of exhaled breath. Analytical and Bioanalytical Chemistry, 406, 4757-4763.

Wang, Y., Hu, Y., Wang, D., Yu, K., Wang, L., Zou, Y., Zhao, C., Zhang, X., Wang, P., \& Ying, K. (2012). The analysis of volatile organic compounds biomarkers for lung cancer in exhaled breath, tissues and cell lines. Cancer Biomarkers, 11, 129-137.
Xu, Z. Q., Broza, Y. Y., Ionsecu, R., Tisch, U., Ding, L., Liu, H., Song, Q., Pan, Y. Y., Xiong, F. X., Gu, K. S., et al. (2013). A nanomaterial-based breath test for distinguishing gastric cancer from benign gastric conditions. British Journal of Cancer, 108, 941-950.

Zaric, B., Petrovic, S., Bjekic, M., Rajic, I., Popovic, A., \& Dordevic, D. (2014). Analysis of human exhaled breath in a population of young volunteers. Archives of Biological Science, 66, 1529-1538.

Zeliger, H. I., Pan, Y., \& Rea, W. J. (2012). Predicting co-morbidities in chemically sensitive individuals from exhaled breath analysis. Interdisciplinary Toxicology, 5, 123-126. 